\title{
Improving Students' Vocabulary Mastery by Using Banana Race Game at the First Grade of SMP Negeri Bangkelekkila
}

\author{
M. Dahlan Bahang*, Rina Asrini Bakri, Febrianti Mentaruk \\ English Department of STKIP-YPUP, Makassar, South Celebes, Indonesia.
}

\begin{abstract}
How to cite this paper: M. Dahlan Bahang*, Rina Asrini Bakri, Febrianti Mentaruk. (2021). Improving Students' Vocabulary Mastery by Using Banana Race Game at the First Grade of SMP Negeri Bangkelekkila. The Educational Review, USA, 5(3), 46-51.

DOI: 10.26855/er.2021.03.003
\end{abstract}

Received: January 31, 2021

Accepted: February 28, 2021

Published: March 16, 2021

Corresponding author: M. Dahlan Bahang, English Department of STKIP-YPUP, Makassar, South Celebes, Indonesia.

Email: mdahlan.hbahang@gmail.com

\begin{abstract}
The objective of the research is to find out whether or not Banana Race Game strategy can improve the students' vocabulary mastery of SMP Negeri 1 Bangkelekila. The research applied pre-experimental method. The population of this research was the first grade students of SMP Negeri 1 Bangkelekila which consists of three classes. The researcher used purposive sampling technique. The total sampling of this research was 22 students. The result of this research found that the comprehension of students' on noun was significantly increased particularly countable nouns and uncountable noun. The mean score of the students post-test was higher than the pre-test scores $(80.31>53.40)$. Furthermore, the t-test value was greater than the t-table value $(9.278>2.080)$. In other word, the banana race game can improve the students' mastery of vocabulary on nouns, particularly for countable nouns and uncountable nouns.
\end{abstract}

\section{Keywords}

Banana Race Game, Vocabulary Mastery

\section{Introduction}

Language is one of the most important things in communication and it is used as a tool of communication among the nation in all over the world. As one of the international language, which is very important and has many interrelation with various aspects of life owned by human being. In Indonesia, English is taught from primary school, junior high school, senior high school and at university, it is taught as a foreign language. Therefore, it is important in this area as a means of transferring science, technology, art, culture, and maintain a good relationship with other countries. In teaching learning process, English has four skills that should be mastered by the students, namely speaking, reading, listening and writing. The above four skills are closely related, and cannot be differentiated from one another.

In general cases, vocabulary is taught by memorizing words without understanding the words. As a researcher, creating effective and efficient English teaching is not an easy task. Besides able to organize teaching and learning activities, the researchers must also present the materials using appropriate teaching techniques. In addition, the teaching and learning process of English cannot be separated from the curriculum or syllabus. The researcher only focuses on teaching vocabulary, because it is an important thing that must be studied first. But in reality, the students sometimes are interested in learning English, they think memorizing each vocabulary is very difficult. In fact, many students cannot express their ideas and opinions well because they are not accustomed to talking, feel shy, hesitant and afraid to make mistakes because of limited vocabulary (Paramadita, 2017). Vocabulary is one of the English components that should be taught by the learners, because it is the main role in all languages. In understanding the words and their meanings, 
the learners must also know how the words work together in good sentence. Therefore, it can be concluded that in teaching vocabulary it is not only giving the meaning of the word but also teaching how the words work in sentence.

Based on the observation of the researcher, conducting a teaching research at SMP Negeri 1 Bangkelekila on September 2020 especially the first grade, the researcher found out that the English language skills of the students do not reach the standard competencies particularly vocabulary mastery. It is also supported from the English teacher Mr. Radu while doing an interview, he said that the students are difficult in learning vocabulary.

The students are difficult in distinguishing vocabulary forms of words such as parts of the speech (nouns, verbs, adjectives and adverbs). In other words, the students tend to get boring with getting new vocabulary. That is why the students' motivation in learning English vocabulary should be improved by using new ways or technique in order to make them interested in learning English. One strategy that keeping the students' motivation in learning English vocabulary by using appropriate methods, techniques and games which facilitate their awareness of vocabulary strategies that they can use to learn in their daily activities is Banana Race Game method. Banana Race Game is one of the games that is suitable for increasing students' motivation in learning English vocabulary.

According to Anngereini (2016), Banana Race Game is a banana racing game for the whole class that encourages students to learn vocabulary and transfer their vocabulary between their friends. The Banana Race game is a fun way for students to practice their English while enjoying some competition.

Based on the explanation above, the researcher is interested in conducting a research entitled "Improving Students' Vocabulary Mastery by Using Banana Race Game at SMP Negeri 1 Bangkelekila”.

\section{Problem Statement}

The problem statement of this research is "Does Banana Race Game improve the students' vocabulary mastery of the first grade students’ SMP Negeri 1 Bangkelekila?”.

While the objective of the research is to find out whether or not Banana Race Game improves the students' vocabulary mastery of the first grade students' of SMP Negeri 1 Bangkelekila.

Referring to the research problem, the result of the study hopefully can give a useful contribution and information for English teachers and other researchers. It is hoped that that this strategy can be used in teaching English vocabulary in order to increase the students' English vocabulary mastery.

The scope of the research focused in teaching vocabulary by using banana race game for the first grade students of SMP Negeri 1 Bangkelekila. The research was limited in measuring the students' noun (countable nouns and uncountable nouns).

\section{Review of Related Literature.}

This part deals with the previous related studies, theories or concept related to the thesis' topic, resume, conceptual framework and hypothesis of the research.

\subsection{Previous Related Findings}

Visual aids are things that you can look at, such as a film, model, map or slides to help you something to remember easy vocabularies (Collins Dictionary, 2019). According to Angereini in her research (2016), said that banana race game could improve the students’ vocabulary at the fifth grade students’ of MI Muhammadiyah Jati Kulon Kudus.

Bafadal and Humariah (2019) conducted a research entitled "The Use of Charades Game to Improve Students Vocabulary". He concludes that the use of Charades Game is a game to make a mental image of a word to aid in recalling the words. In other words, the charades game could help the students to remember the words easily. While according to Arsyad in Hanapi (2016), sated that there are three kinds of media that can be used to teach and learn English vocabulary easily such as visual media, audio media and audio visual media.

March (2013) conducted a research entitled "Increasing Students mastery of English vocabulary through Word Snake Game”. He concludes that word snake game will help the students increase their vocabulary, as this game is played with the awareness of the teachers and it is similar to create a crossword, but it is easier in adapting to various rules and teaching levels.

Referring to the previous findings above, there are several opportunities to improve students' vocabulary mastery. Each person or student has unique features that are different from the others and using many ways to improve vocabulary. Therefore, the researchers are required to use banana racing game that can improve students' vocabulary with daily vocabulary. 


\subsection{Some pertinent Ideas}

Teaching English vocabulary tends to be one $f$ the main problems, since language implementation is a fundamental condition to communicate thought, emotion, temperament and desires. This must be the distinguished between word and vocabulary. True vocabulary is the word itself but its meanings are different in language. Some experts place the basic definition of vocabulary as the number of words language that someone knows or understand where he can speak, read, write or listen. According to Richards in Lisdawati, Y. Sofian, and Supardi (2017), stated that vocabulary is a core component of language proficiency and provides much of the basis for how well learners speak, listen, read and write. It means knowing and having enough vocabulary, someone or a language learner will be difficult to understand the other language skill such as speaking, reading, writing and listening. Vocabulary is one of the items that have to be mastered first by the students in learning English, because no one can speak if they have limited vocabulary and without a proportional amount of vocabulary anyone will get trouble in the process of learning English. According to Lelawati and Mailani (2018), vocabulary is a supply of words for speaker or a writer. The terms of vocabulary can refer to all words in an entire language, words or phrases used in particular group such as variations in language, notes and terms. Vocabulary is the highest ability that must be mastered by the reader or writer, words used at the point of knowledge, and list of words arranged such as in a dictionary, complete with a clear and concise explanations.

Harmer in Amri (2016), states that there are two types of vocabulary, they are as follows:

1. Active vocabulary refers to the vocabulary that the students have been taught or have learned and which they are expected to be able to use.

2. Passive vocabulary refers to the vocabulary that the students do not frequently use but can be recognized and understood the meaning both in textual and oral contexts.

Thornbury in Putri (2017) said that there are six kinds of vocabulary namely:

1. Words classes. Words classes are part of speech. They are divided into eight classes such as noun, pronoun, verb, adjective, adverb, preposition, conjunction and determiner. There are two types of noun, they are countable noun and uncountable noun. Countable noun can usually be made plurals for example boy—boys, lady—ladies. While countable noun is a noun which does not have a plural form and this refers to something that could not be counted (Frank, 1972).

2. Word families which discusses about affixation, inflection and derivatives.

3. Word formation.

4. Multi word units.

5. Collocation and

6. Word meaning. According to Edge in Kusrini (2012), the more words you know, the better chance of understanding or making yourself understood. It means that vocabulary is very important. It is also show how important the vocabulary is. Bromley in Octaviani (2019) stated that vocabulary holds some important roles in teaching learning process. They are promoting fluency, boosting comprehension, improving achievement and enhancing thinking and communication.

Wright in Maulidah (2009) said that game is an activity which entertaining and engaging, often challenging, and an activity in which the learners play and usually interact with others. The aim of recommending games for vocabulary learning is to create conditions which encourage vocabulary expansion. Games are effective ways to make students more enjoying in teaching learning process. Besides that, games make the students are more active, creative and make them interested in learning English vocabulary. It can be concluded that games are one of the activities as a bridge to make students communicate to each other especially in learning process. According to Lewie and Bedson (2014), divided games to their general character and spirit such as movement game, card game, board game, dice game, drawing game team game, word game, and guessing game. From some of the games that have been used by some researchers previously, then researcher will only focus on banana race game which is interesting, fun and can make the students more active in class and the game can improve students' vocabulary.

Angreini (2016) stated that banana racing game for the whole class that encourages students to learn vocabulary and transfer their vocabulary to other students. It is a fun way for students to practice their English while enjoying some competition. The banana race game is very interesting and may stimulate the students' activities in the class. The procedures in learning and teaching using banana race game are as follows:

1. Students will be divided into several groups;

2. Each students sits according to their respective groups;

3. The teacher will say a word and the students listen to what the teacher says carefully;

4. One student from each team race to the blackboard or whiteboard to write the word said by the teacher;

5. After they have written the word, they will spell and say it in front of their friends; 
6. The teacher knows the winner by listening the first one who spell and say the word correctly;

7. A students who is the winner will get a point for their team lastly;

8. Each team has his chance, and there is one team as the winner.

\section{Method of the Research}

In this research, the researcher used pre-experimental method which has three steps namely pre-test, treatment and post-test.

The researcher applied pre-experimental design which one group pre-test and post-test. The design involved one group pre-test (01), treatment (X) and post-test (02). The systemic design of this research is presented as follows:

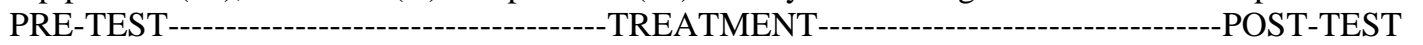

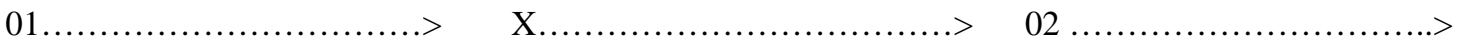

Where:

$01=$ the result of the students' pre-test

$\mathrm{X}=$ the treatment

$02=$ the result of the students' post-test

There were two variables in this research namely: independent variable and dependent variable. Independent variable was the use of banana race game in teaching vocabulary mastery and dependent variable was the students' vocabulary mastery.

The population of this research was the first grade students of SMP Negeri 1 Bangkelekila that consisted of three classes, namely VII A which consisted of 22 students, VII B which consisted of 22 students and VII C which consisted of 22 students also. So, the total number of population was 66 students.

The researcher applied purpose sampling technique. The researcher took VII B that consisted of 22 students. This class was chosen because the students' vocabulary mastery was very low beside mathematic subject.

In collecting the data, the researcher used multiple choice test which consisted of 50 items. The test was done in order to know the students' vocabulary mastery in pre-test and post-test. The pre-test was intended to find the students' prior knowledge of English vocabulary while post-test was intended to find the students' vocabulary mastery after treatment by using banana race game strategy.

In collecting the data, the researcher used three steps namely:

1. Pre-test. The pre-test was given just to find out the students' prior knowledge of vocabulary before the treatment by using banana race game strategy.

2. Treatment. The treatment was done for four meeting by using banana race game strategy in teaching vocabulary. Each meeting took 90 minutes.

3. Post-test. After treatment, the researcher provided post-test to find out the students' result after treatment.

\section{Finding and Discussion}

This parts dealing with the finding of the research and discussion of the findings. The findings are ordered in line with the problem statement stated in the introduction part. In discussion part, arguments and further interpretation of the findings are given.

The finding of the research was dealing with the students' score of pre-test (XI) and post-test (X2), the frequency and rare percentage of the students score in pre-test and post-test, the mean score of pre-test and post-test, the t-test value and hypothesis testing. As a finding in this research, the researcher collected the data by using procedure of collecting data as have already explained in chapter III. The researcher gave a test and treatment. There were some findings that found in test and treatments. The clarified findings are as follow:

The students' score in pre-test are classified into some criteria. The criteria were very good, good, average, poor, and very poor.

The result of the students' pre-test was very low. It can be seen that there were six students who got sixty five (65) score, there were five students got fifty five (55) score, three students got fifty (50) score. Therefore, there were sixteen students whose vocabulary can be classified as average in the range score of 50-65. There were three students who got forty five (45) score, there was one student got 40 score, there was one student got 35 score, there was one student got 30 score. Therefore, there were six students whose vocabulary can be classified as poor in the range of 30-49.

The describing data above shows that the highest score of the students' pre-test result was 65 that consisted of six students, and the lowest score was 30 that was one student. The total score of pre-test were 1,175 and the mean score were 53.40. The data were clearly explained that the students' vocabulary mastery was still low. From the result, it could be concluded that the students were very low in answering their vocabulary test. In this case, the result of the stu- 
dents' vocabulary mastery was very low. The rate percentage and frequency of the students' pre-test showed that none of the student (0\%) was classified into very good, sixteen students (73\%) were classified into average, and six students (27\%) were classified into poor.

After giving treatment by using banana race game, the researcher found out that the strategy was effective in improving students' vocabulary mastery by giving post-test. In the post-test, the researcher found that many of the students were able to answer the question given. They were enthusiasm to do the test and it seemed of the expression on the students' faces when doing the test. Besides that they did the test so fast and collected their working sheet before the time finish.

In order to measure the students' understanding about the material given and the effectiveness of the strategy, the researcher prepared the second test. The researcher gave the post-test after the researcher delivered the treatment. It aimed to find out the students' improvement after they have learned vocabulary by using banana race game. Based on the post-test, score after using banana race game strategy within four meetings has succeeded to change the students' very poor score in the pre-test into good in post-test.

The score of post-test showed that there were two students got ninety seven (97) score from the total number students of 22, there were three students got ninety three (93) score, there was one student got ninety (90) score, there were three students got eighty five (85) score, there were two students got eighty (80) score, there was one student got seventy nine score, there were students got seventy five score, there were six students got seventy score and there was one student got sixty five (65) score. The data from the post-test results showed that the highest score was 97 score that consisted of two students and the lowest score was 65 that was consisted one student. The total score of post-test was 1,797 and the mean score was 80.31 .

From the result above, it can be concluded that the students' vocabulary mastery by using banana race game has been improved. In pre-test, $0 \%$ student was classified as very good while in pos-test, there were $50 \%$ students classified as very good. $0 \%$ student was classified as good in pre-test while in post-test, there were $45.54 \%$ students classified as good. In pre-test, there were $73 \%$ was categorized as average score while in post-test $4.55 \%$ was categorized as average score. In pre-test, there were $27 \%$ students was categorized as poor score and in post-test, there was none students got poor classification and there were none of the students in pre-test and post-test got very poor classification.

The mean score of student' pretest (XI) was 80.31 from the total score 1767 while the mean score of gain (D) was 26.90 from the total score 592. It can be concluded that the mean of post-test score was greater than the mean score of pre-test. It means that the use of banana race game could improve the students' vocabulary mastery at first grade students of SMP Negeri 1 Bangkelekila.

\section{Conclusion and Suggestion}

This chapter deals with the conclusion and suggestion of the research.

This strategy was successfully in increasing the students' vocabulary mastery by using banana race game strategy. The implementation of banana race game strategy provided the students opportunities to answer the question, to dramatize and style of recitation materials given during the teaching and learning process of vocabulary. It is expected that the teacher can use this strategy in their teaching vocabulary subject since the students are happy in doing their tasks and answering the questions on time.

Based on the data analysis, research finding and discussion in the previous chapter the researcher formulates a conclusion as follow.

The use of banana race game strategy as treatment of the research was applied in teaching vocabulary. The students achievement can be improved from post-test mean score (80.31) which is higher than the pre-test mean score (53.40)

The researcher concluded that by using banana race game was effective in improving the students' vocabulary mastery at the first grade students of SMP Negeri 1 Bangkelekila. They were active in classroom because the banana race game was nice way in learning and can easily master new words and memorized them easily. Beside that banana race game strategy is a good model that can be applied in the classroom. Using banana race game in teaching is not only effective way in improving students' vocabulary mastery, but also improving students' understanding the materials. Finally, the situation of the teaching and learning process become more enjoyable and interesting.

Based on the result of the data analysis and the conclusion above, the researcher formulate some suggestions below.

1. The researcher suggests English teachers to use banana race game in teaching and learning process especially in teaching vocabulary.

2. The teacher should be creative in teaching and avoid the boredom of students.

3. The teacher also could use o good model in teaching to make the students interested in learning the lesson.

4. The teachers should give chances for the students to practice more and not feel shy because they in group. 
5. Finally, the researcher suggests that the students should enrich their vocabulary from many different sources such as English film, books or newspaper written in English, dictionary and use their hand phone as well.

\section{References}

Amri, U. (2016). Increasing Students’ Vocabulary Mastery by Using Eye-Spy Game at the Second Grade of SMP Babuss Alam Selayar. Repositori.uin-alauddin.ac.id/6172/1/Ulil Amri.pdf.

Anggraeni, Lia. (2016). Improving the Vocabulary Mastery of the Fifth Grade Students at MI Muhammadiyah Jati Kulon Kudus Taught by Using Banana Race Game.

Arumningsih, D. W. L., Program, E. E., Training, T., and Faculty E. (2017). The Effectiveness of Using Spelling Bee Game in Teaching Vocabulary at the Seventh Grade Students of MTS Al-Hidayah Nusawungu.

Bafadal, M. F. and Humaira, H. (2019). The Use of Charades Game in Teaching Vocabulary to Junior High School Students. Linguistics and ELT Journal, 5(1), 14. https://doi.org/10.31764/leltj.v12i2. 748.

Dani, Yuni Luthfita. (2015). The Effectiveness of Eat Bulaga Game for Teaching Vocabulary of Mts Pp Darul Qurro Kawunganten. Bachelor Thesis. Universitas Muhammadiyah Purwokerto. https://repository.ump.ac.id/3402/.

Dawson, Collin. (1985). Teaching as Foreign Language. Hong Kong. Collins. W. (nd). Collin Dictionary Retrieved November 11, 2019. From Collins. https:///www.collinsdictionary.com/visual media.

Hanapi. (2016). Teaching and Learning Vocabulary by Using Visual Media to Students. IAIN Raden Intan Lampung.

KUsmawati, F. P. (n.d.). Board Race to Boost Students’ Vocabulary Mastery. December 2017, 15-16.

Lelawati, S., Dhiya, S., and Mailani, P. S. (2018). The Teaching of English Vocabulary to Young Learners. Download from https://journal.ikipsiliwangi.ac.id. Accesed on May 19, 2020, 11:31 PM.

Putri, A. M. (2017). The Use of 20 Squares: Add One More Word and Word Clap Games to Teach Vocabulary Faculty of Languages and Arts. Pp. 1-90. 